MATEC Web of Conferences 9, 04001 (2013)

DOI: $10.1051 /$ matecconf/20130904001

(C) Owned by the authors, published by EDP Sciences, 2013

\title{
Experimental study on fire propagation over combustible exterior facades in Japan
}

\author{
Yuhei Nishio ${ }^{1}$, Hideki Yoshioka ${ }^{2}$, Takafumi Noguchi ${ }^{1}$, Tatsuo Ando ${ }^{3}$ \\ and Masamichi Tamura ${ }^{1}$ \\ ${ }^{1}$ The University of Tokyo, Japan \\ ${ }^{2}$ National Institute for Land and Infrastructure Management (NILIM), Japan \\ ${ }^{3}$ Mitsubishi Plastics, Inc., Japan
}

\begin{abstract}
With regard to the fire protection for exterior walls of building, only the fire resistance has been considered, according to the current building law of Japan. In the previous studies of the authors, a new test method for evaluation of fire propagation along combustible cladding was proposed using primarily test specimens of façade walls with exterior thermal insulation without vent layers. In this paper, newly obtained test results are discussed on other specimens of combustible façades such as wood, sandwich panel, photovoltaic sheet mounted on composite panel, combustible coating material, and exterior thermal insulation with vent layer.
\end{abstract}

\section{INTRODUCTION}

According to the current building law of Japan, it is not restricted to install combustible materials over their exterior walls as long as fireproof buildings retain their required fire resistance. However, it is not exactly evaluated how flame will propagate along the combustible façades. From the past fire accident such as TVCC Building in Beijing, China, it was revealed that installation of combustible material over the exterior wall could cause large-scale flame and fire propagation.

Regarding combustion of exterior façades, proper standards have not been specified in Japan. It is urgently necessarily to establish test method and performance evaluation for combustible exterior façades.

The authors have conducted several studies about wet finishing exterior insulation walls for evaluating performance of combustion. The façade fire test method, which the authors have conducted, is a method to generate ejected flame from opening of the chamber. In the previous studies of the authors, façade test method for evaluation of flame propagation along combustible cladding was proposed, using primarily test specimens of façade wall with exterior thermal insulation without vent layer or air cavity [1].

In this paper, the results of fire experiments are reported not only on test specimens with the wet finishing exterior insulation construction but also on those with other combustible façades (e.g. sandwich panel, photovoltaic sheet mounted on composite panel, ventilation layer construction method, wood).

\section{OUTLINE OF THE EXPERIMENTS}

To evaluate the fire propagation properties of test specimens reproducing various types of combustible façades on the outside of the exterior load-bearing wall, presuming a fire scenario where an interior fire has occurred in a compartment, the flame is ejected from an opening.

This is an Open Access article distributed under the terms of the Creative Commons Attribution License 2.0, which permits unrestricted use, distribution, and reproduction in any medium, provided the original work is properly cited. 


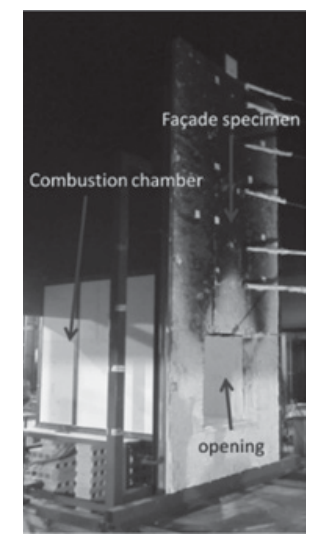

Figure 1. Test apparatus.

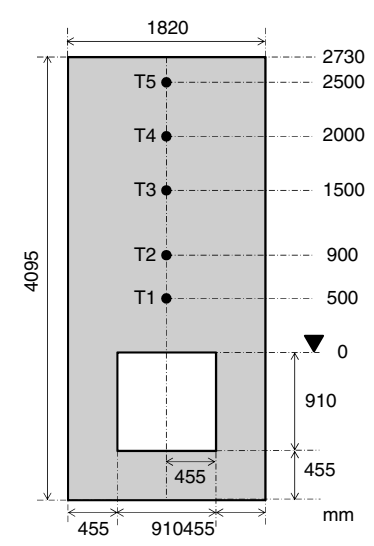

Figure 2. Shape of test specimen.

As shown in Figure 1, after vertically installing the façade test specimen $(4,095 \mathrm{~mm}$ high $\times$ $1,820 \mathrm{~mm}$ wide), the opening of the test specimen was attached to the combustion chamber (inner dimension: $1,350 \mathrm{~mm}$ high $\times 1,350 \mathrm{~mm}$ wide $\times 1,350$ or $1,650 \mathrm{~mm}$ deep), and the burner inside the chamber ( $600 \mathrm{~mm}$ square, centrally installed at the backwall of the chamber) was ignited to make flames gashing from the opening. The heating intensity of the burner was set at $600 \mathrm{~kW}$ and heating time for 20 minutes, and thermocouples (top exterior surface of façade test specimen) were installed at five points (500 mm, $900 \mathrm{~mm}, 1,500 \mathrm{~mm}, 2,000 \mathrm{~mm}$ and 2,500 $\mathrm{mm}$ from the upper edge of the opening).

The frame is composed of light-gauge steels and the whole exterior surface side (heating side) cladded with calcium silicate boards. All test specimens were applied in accordance with ordinary construction methods and practice in actual buildings.

\section{TEMPERATURES MEASURED AT NONCOMBUSTIBLE FACADE SURFACE}

In order to measure the temperature when heated without combustible materials on the exterior wall side, calibration tests were performed before façade tests. As a calibration test specimen, ceramic fibre blankets ( $25 \mathrm{~mm}$ thick) were installed on the outside of the calcium silicate boards. Installation positions of thermocouples are indicated by marks • (T1 - T5) in Figure 2. 
Table 1. Temperatures during calibration tests (average values in ${ }^{\circ} \mathrm{C}$ ).

\begin{tabular}{|c|c|c|c|c|c|c|}
\hline No. & Heat intensity & T1 & T2 & T3 & T4 & T5 \\
\hline 1-B & $600 \mathrm{~kW}$ & 434 & 374 & 280 & 221 & 189 \\
\hline 2-B & $600 \mathrm{~kW}$ & 420 & 345 & 277 & 223 & 186 \\
\hline
\end{tabular}

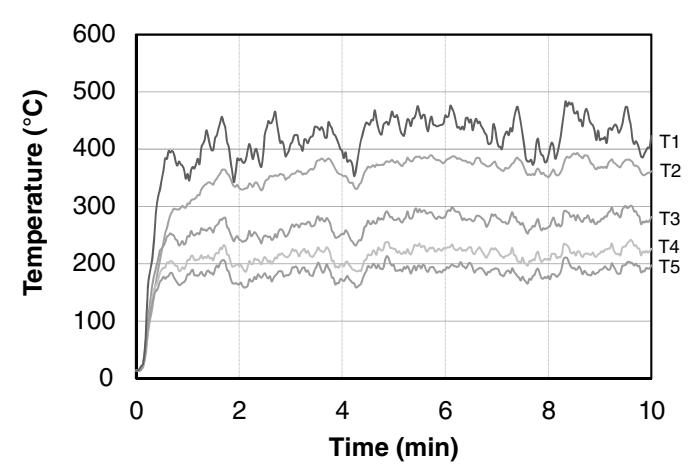

No.1-B

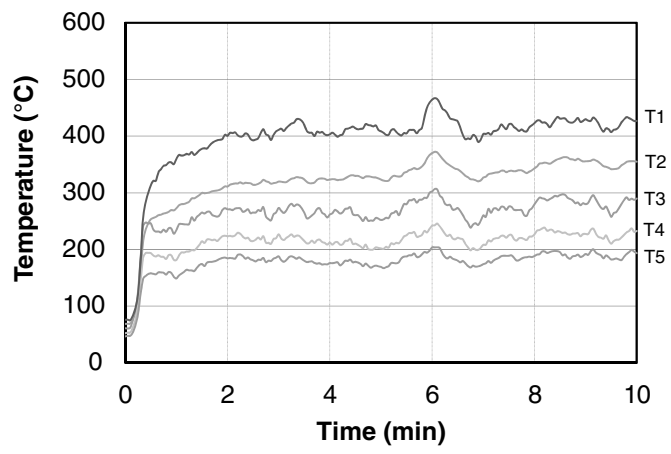

No.2-B

Figure 3. Façade surface temperature during calibration tests.

Façade calibration tests were conducted twice. First, the combustion chamber has the inner dimension of $1,350 \mathrm{~mm}$ high $\times 1,350 \mathrm{~mm}$ wide $\times 1,650 \mathrm{~mm}$ deep (1-B). Second, the other combustion chamber has the inner dimension of $1,350 \mathrm{~mm}$ high $\times 1,350 \mathrm{~mm}$ wide $\times 1,350 \mathrm{~mm}$ deep (2-B). The target of heating intensity in the combustion chamber was set at $600[\mathrm{~kW}]$, which refers to a calculation value on the assumption that propane gas was completely combusted. Table 1 indicates the result of the average values between 5 to 10 minutes from the initiation of tests, and Figure 3 shows chronological changes of the temperatures on the facade surface.

Comparing 1-B with 2-B, slightly higher temperatures were measured in 1-B due to the difference of the depth into combustion chambers. All the combustible specimens will be subjected to similar flame venting through opening.

\section{FIRE PERFORMANCE OF COMBUSTIBLE FAÇADE TEST SPECIMENS}

To perform fire tests with combustible façade specimen, the time was set for 20 minutes and the target heating intensity in the combustion chamber was $600[\mathrm{~kW}]$ except for two cases (No. 2-16 and 2-17).

\subsection{Category of the combustible façade specimens}

The details of combustible façade specimens are summarized at Tables 2 and 3.

Each test specimen has an identical dimension $(4,095$ high $\times 1,820 \mathrm{~mm}$ wide), and was firmly attached outside of calcium silicate boards as substrate. With regard to vertical joint of a façade specimen, it was decided to basically use a vertical joint at the centre line in order to clarify the impact of the joint, though it is not realistic to allocate a joint at the upper centre of an opening in actual buildings. Two types of façade tests were performed, first on specimens of No.1-1to No.1-13 (Fig. 4), and then on specimens of No.2-1 to No.2-19 (Fig. 5). The main differences are the location of thermocouples on the surface and the depth of combustion chamber. In the first series, the combustion chamber has the inner dimension of $1,350 \mathrm{~mm}$ high $\times 1,350 \mathrm{~mm}$ wide $\times 1,650 \mathrm{~mm}$ deep and installation positions of thermocouples are indicated by marks $\bullet(\mathrm{T} 1-\mathrm{T} 5)$ in Figure 4 . In the second series, temperatures were measured $227.5 \mathrm{~mm}$ sideways from the central vertical joint as in Figure 5, in order to avoid direct 


\section{MATEC Web of Conferences}

Table 2. Combustible facade specimens (No. 1-1 to 1-13).

\begin{tabular}{|c|c|c|c|}
\hline No. & Classification & Details & $\begin{array}{l}\text { Vertical } \\
\text { joint }\end{array}$ \\
\hline $1-1$ & \multirow{2}{*}{$\begin{array}{l}\text { Exterior thermal insulation } \\
\text { with vent layer }(20 \mathrm{~mm})\end{array}$} & $\begin{array}{l}\text { Phenolic foam }(50 \mathrm{~mm} \text { thick); Surface: } \\
\text { galvalume steel plate }\end{array}$ & \multirow{2}{*}{ Without } \\
\hline $1-2$ & & $\begin{array}{l}\text { XPS(50 mm thick); Surface: galvalume steel } \\
\text { plate }\end{array}$ & \\
\hline $1-3$ & \multirow{2}{*}{$\begin{array}{l}\text { Sandwich panel } \\
(50 \mathrm{~mm} \text { thick })\end{array}$} & $\begin{array}{l}\text { Core: polyisocyanurate foam }(49 \mathrm{~mm} \text { thick); } \\
\text { Surface: coated steel plate }(0.5 \mathrm{~mm} \text { thick }) \text { on } \\
\text { both sides; Opening frame: none; Edge: ceramic }\end{array}$ & \multirow{5}{*}{ With } \\
\hline $1-4$ & & $\begin{array}{l}\text { Core: polyurethane foam }(49 \mathrm{~mm} \text { thick }) \text {; Surface: } \\
\text { coated steel plate }(0.5 \mathrm{~mm} \text { thick }) \text { on both sides; } \\
\text { Opening frame: steel sheets; Edge: vinyl } \\
\text { chloride }\end{array}$ & \\
\hline $1-5$ & Composite panel (4 mm) & $\begin{array}{l}\text { Core: fire-retardant polyethylene }(3 \mathrm{~mm} \text { thick); } \\
\text { Surface: aluminium facing }(0.5 \mathrm{~mm} \text { thick }) \text { on } \\
\text { both sides }\end{array}$ & \\
\hline $1-6$ & $\begin{array}{l}\text { Photovoltaic sheet on } \\
\text { composite panel (1-5) }\end{array}$ & $\begin{array}{l}\text { Base material is composite panel (Same as } 1-5) \text {; } \\
\text { Photovoltaic sheet }(1.3 \mathrm{~mm} \text { thick) mounted on } \\
\text { the surface }\end{array}$ & \\
\hline $1-7$ & \multirow{5}{*}{$\begin{array}{l}\text { Exterior thermal } \\
\text { insulation (wet finishing) }\end{array}$} & $\begin{array}{l}\text { EPS }(50 \mathrm{~mm} \text { thick);SBR system polymer cement } \\
\text { mortar( } 4 \mathrm{~mm} \text { thick); reinforcing net( } 2 \text { layers); } \\
\text { Edge: aluminium frame; Finishing material: } \\
\text { fire-retardant }\end{array}$ & \\
\hline $1-8$ & & \multirow{2}{*}{$\begin{array}{l}\text { EPS(50 mm thick); Acrylic resin mortar( } 2 \mathrm{~mm}) \text {; } \\
\text { Reinforcing net(single layer); Edge: back- } \\
\text { wrapping; Finishing material: combustible }\end{array}$} & Without \\
\hline $1-9$ & & & With \\
\hline $1-10$ & & Same as $1-8$ except thickness of EPS $(100 \mathrm{~mm})$ & \multirow[t]{2}{*}{ Without } \\
\hline $1-11$ & & $\begin{array}{l}\text { Almost the same as 1-10 except other company } \\
\text { constructed }\end{array}$ & \\
\hline $1-12$ & Resin painting & $\begin{array}{l}\text { Water resistant exterior finish paint on substrates } \\
(2 \sim 3 \mathrm{~mm} \text { thick })\end{array}$ & Without \\
\hline $1-13$ & Resin siding boards & Extruded vinyl chloride resin with furring & With \\
\hline
\end{tabular}

influence of joint combustion. This time, the combustion chamber has the inner dimension of $1,350 \mathrm{~mm}$ high $\times 1,350 \mathrm{~mm}$ wide $\times 1,350 \mathrm{~mm}$ deep.

Specimens are mainly classified as sandwich panel, wood, exterior thermal insulation with vent layer, exterior thermal insulation (wet finishing), photovoltaic sheet mounted on composite panel, etc.

\subsection{Exterior thermal insulation with vent layer}

As exterior thermal insulation with vent layer, façade tests were conducted with 4 specimens. No.1-2 was prepared simulating TVCC Building in Beijing, which was damaged a massive fire on February 9 , 2009.

Main differences between specimens are shown in Table 4. Two thermal insulation materials (XPS or phenolic foam) with or without reinforcement of the opening were conducted. For the reference, a façade test to the specimen without thermal insulation was conducted (No.2-1).

Measured temperatures on the surface during the tests were not so high because the surface was covered with steel plate and thermal insulations are located inside of vent layer. But shown in Figure 6, 
$1^{\text {st }}$ International Seminar for Fire Safety of Facades, Paris (France), 2013

Table 3. Combustible facade specimens (No. 2-1 to 2-19).

\begin{tabular}{|c|c|c|c|}
\hline No. & Classification & Details & $\begin{array}{l}\text { Vertical } \\
\text { joint }\end{array}$ \\
\hline $2-1$ & \multirow{2}{*}{$\begin{array}{l}\text { Exterior thermal insulation } \\
\text { with vent layer }(20 \mathrm{~mm})\end{array}$} & $\begin{array}{l}\text { No thermal insulation; Surface: } \\
\text { galvalume steel plate }\end{array}$ & \multirow{2}{*}{ Without } \\
\hline $2-2$ & & $\begin{array}{l}\text { Phenolic foam }(50 \mathrm{~mm} \text { thick }) \\
\text { Surface: galvalume steel plate }\end{array}$ & \\
\hline $2-3$ & \multirow{2}{*}{$\begin{array}{l}\text { Sandwich panel } \\
(50 \mathrm{~mm} \text { thick })\end{array}$} & $\begin{array}{l}\text { Core: polyurethane foam }(49 \mathrm{~mm} \text { thick }) \text {; } \\
\text { Surface: coated steel plate }(0.5 \mathrm{~mm} \text { thick }) \text { on } \\
\text { both sides; Opening frame: none; Edge: ceramic }\end{array}$ & \multirow{4}{*}{ With } \\
\hline $2-4$ & & $\begin{array}{l}\text { Core: polyisocyanurate foam }(49 \mathrm{~mm} \text { thick }) \text {; } \\
\text { Surface: coated steel plate }(0.5 \mathrm{~mm} \text { thick }) \text { on both } \\
\text { sides; Opening frame: steel sheets; Edge: vinyl } \\
\text { chloride }\end{array}$ & \\
\hline $2-5$ & Composite panel (4 mm) & $\begin{array}{l}\text { Core: fire-retardant polyethylene }(3 \mathrm{~mm} \text { thick }) \text {; } \\
\text { Surface: aluminium facing }(0.5 \mathrm{~mm} \text { thick }) \text { on both } \\
\text { sides }\end{array}$ & \\
\hline $2-6$ & $\begin{array}{l}\text { Photovoltaic sheet on } \\
\text { composite panel(2-5) }\end{array}$ & $\begin{array}{l}\text { Base material is composite panel (Same as 2-5); } \\
\text { Photovoltaic sheet( } 1.3 \mathrm{~mm} \text { thick) mounted on the } \\
\text { surface }\end{array}$ & \\
\hline $2-7$ & \multirow{3}{*}{ Wood } & Horizontal planks of Japanese cedar on furring & \multirow{3}{*}{ Without } \\
\hline \multirow{2}{*}{$2-8$} & & Same as 2-7 expect cedar with chemical treatment & \\
\hline & & $\begin{array}{l}\text { Same as } 2-7 \text { expect cedar with heat and chemical } \\
\text { treatment }\end{array}$ & \\
\hline $2-10$ & \multirow{9}{*}{$\begin{array}{l}\text { Exterior thermal } \\
\text { insulation(wet finishing) }\end{array}$} & $\begin{array}{l}\text { EPS (100 mm thick);SBR system polymer cement } \\
\text { mortar ( } 4 \mathrm{~mm} \text { thick); Reinforcing net( } 2 \text { layers }) \text {; } \\
\text { Anchor pin reinforcement; Finishing material: fire- } \\
\text { retardant }\end{array}$ & \multirow{6}{*}{ With } \\
\hline $2-11$ & & $\begin{array}{l}\text { EPS }(100 \mathrm{~mm}) \text {; Acrylic resin mortar ( } 2 \mathrm{~mm} \text { thick); } \\
\text { Reinforcing } \\
\text { net(single layer); Edge: back-wrapping; Finishing } \\
\text { material: combustible }\end{array}$ & \\
\hline $2-12$ & & $\begin{array}{l}\text { Same as } 2-11 \text { except thickness of EPS }(200 \mathrm{~mm}) \\
\text { and Edge: fireproofing material }\end{array}$ & \\
\hline $2-13$ & & $\begin{array}{l}\text { EPS(50 mm thick); Acrylic resin mortar( } 2 \mathrm{~mm} \\
\text { thick); Reinforcing net(single layer); Edge: back- } \\
\text { wrapping; finishing material: incombustible wood }\end{array}$ & \\
\hline $2-14$ & & $\begin{array}{l}\text { Almost the same as 2-11 except other company } \\
\text { constructed }\end{array}$ & \\
\hline $2-15$ & & Same as 2-14 except thickness of EPS(150 mm) & \\
\hline $2-16$ & & \multirow[t]{2}{*}{ Same as 2-14 except higher heat intensity $(700 \mathrm{~kW})$} & Without \\
\hline $2-17$ & & & \multirow{2}{*}{ With } \\
\hline $2-18$ & & Same as 2-11 except Edge: fireproofing material & \\
\hline $2-19$ & Acrylic sheets & PMMA (1 mm thick) on calcium silicate boards & Without \\
\hline
\end{tabular}

fire propagation occurred on the vent layer. For reference, temperatures in the vent layer on No. 2-2 were measured (Fig. 7). It indicates that thermal insulation was burning in the vent layer during heating. Regarding fire propagation of specimens, there was no noticeable difference due to reinforcement of the opening between No. 1-1 and No. 2-2. 


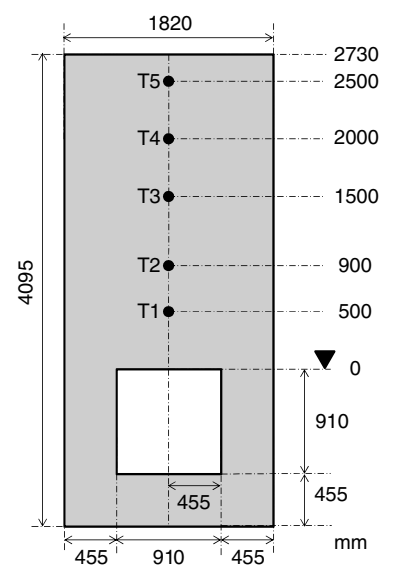

Figure 4. Thermocouple locations(No. 1-1 to 1-13).

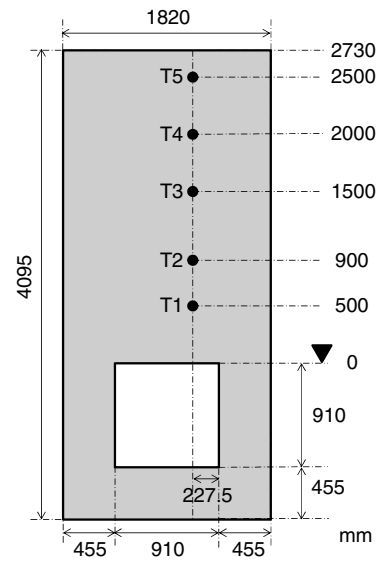

Figure 5. Thermocouple locations (No. 2-1 to 2-19).

Table 4. Composition of specimens (Exterior thermal insulation with vent layer).

\begin{tabular}{|c|c|c|c|c|}
\hline No. & Thermal insulation & Vent layer & Surface & $\begin{array}{l}\text { Reinforcement on } \\
\text { the opening }\end{array}$ \\
\hline $1-1$ & Phenolic foam $(50 \mathrm{~mm})$ & $20 \mathrm{~mm}$ & Galvalume steel plate & \multirow{2}{*}{ None } \\
\hline $1-2$ & $\mathrm{XPS}(50 \mathrm{~mm})$ & $20 \mathrm{~mm}$ & Galvalume steel plate & \\
\hline $2-1$ & None & $20 \mathrm{~mm}$ & & \multirow{2}{*}{$\begin{array}{l}\text { Additional steel sheets on the } \\
\text { upper end of the opening }\end{array}$} \\
\hline $2-2$ & Phenolic foam $(50 \mathrm{~mm})$ & $20 \mathrm{~mm}$ & Galvalume steel plate & \\
\hline
\end{tabular}

\subsection{Sandwich panel $(50 \mathrm{~mm}$ thick $)$}

As for sandwich panel, façade tests were conducted with 4 specimens. Main differences between specimens are shown in Table 5. The tests were conducted using different cores (polyurethane foam or polyisocyanurate foam) with different panel edge (ceramic or vinyl chloride extrusions) and opening frame (with or without steel sheets). 

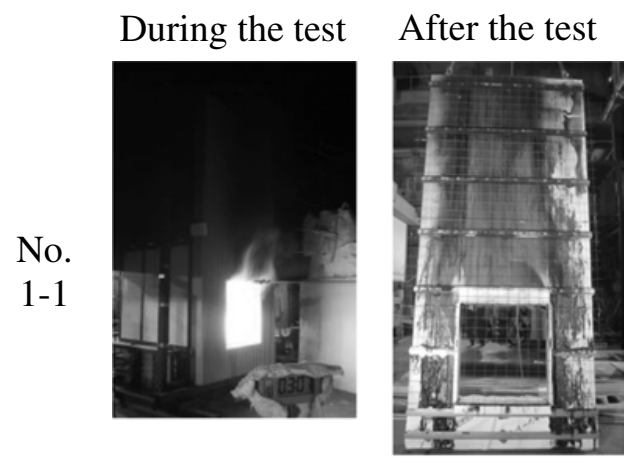

\section{Façade surface temperature}
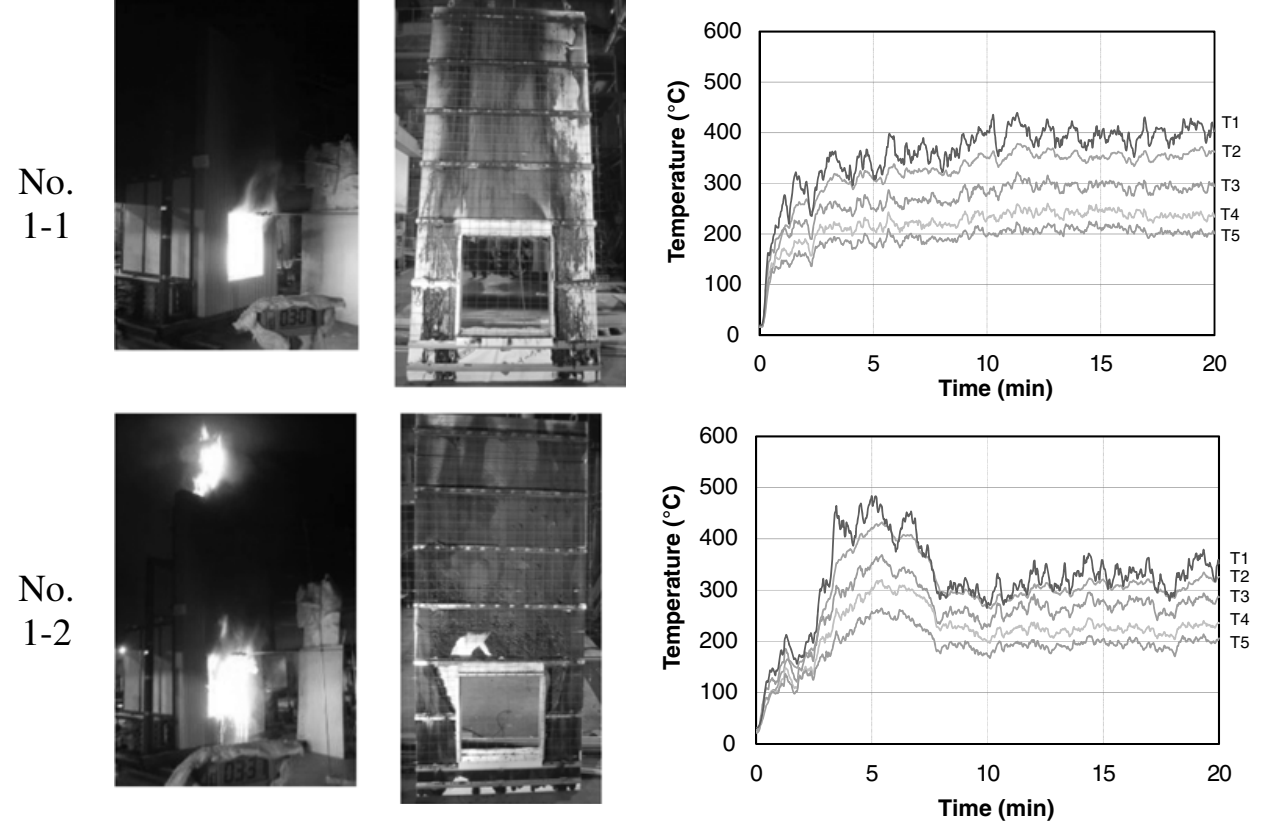

Figure 6. Test result (No. 1-1 and 1-2).

Façade surface temperature

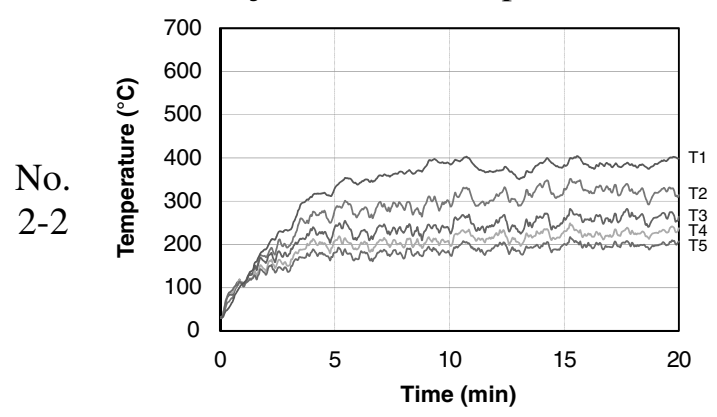

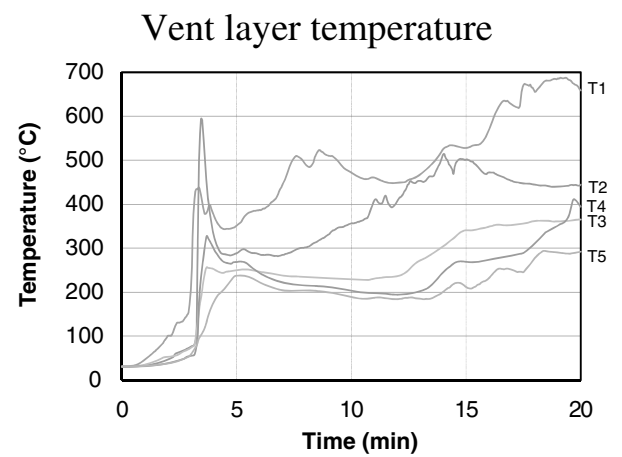

Figure 7. Test result (No. 2-2).

Since the surface of sandwich panel is covered with steel plate, it seemed that fire propagation occurred only at the vertical joint viewed from outside, but cores were also damaged by fire shown in Figure 8. In the case of opening frame without steel sheets but with ceramic edge, the upper part of the opening was broken and core materials fell from around upper part of the opening. But, damaged area of the core was not so different regardless of the opening with or without steel sheets.

On this test for sandwich panel, reinforcement of an opening delayed fire propagation on façade surface, but damaged area after test is almost the same and combustibility of core material has a larger impact on fire propagation of the specimens. 


\section{MATEC Web of Conferences}

Table 5. Composition of specimens (Sandwich panel: $50 \mathrm{~mm}$ thick).

\begin{tabular}{|c|c|c|c|c|}
\hline No. & Core $(49 \mathrm{~mm})$ & Surface & Edge & Opening frame \\
\hline & & \multirow{5}{*}{$\begin{array}{c}\text { Coated steel plate }(0.5 \mathrm{~mm}) \\
\text { on both sides }\end{array}$} & & None \\
\hline $1-3$ & Polyisocyanurate foam(PIR) & & Ceramic & None \\
\hline $1-4$ & Polyurethane foam(PUR) & & Vinyl chloride & Steel sheets \\
\hline $2-3$ & Polyurethane foam(PUR) & & Ceramic & None \\
\hline $2-4$ & Polyisocyanurate foam(PIR) & & Vinyl chloride & Steel sheets \\
\hline
\end{tabular}
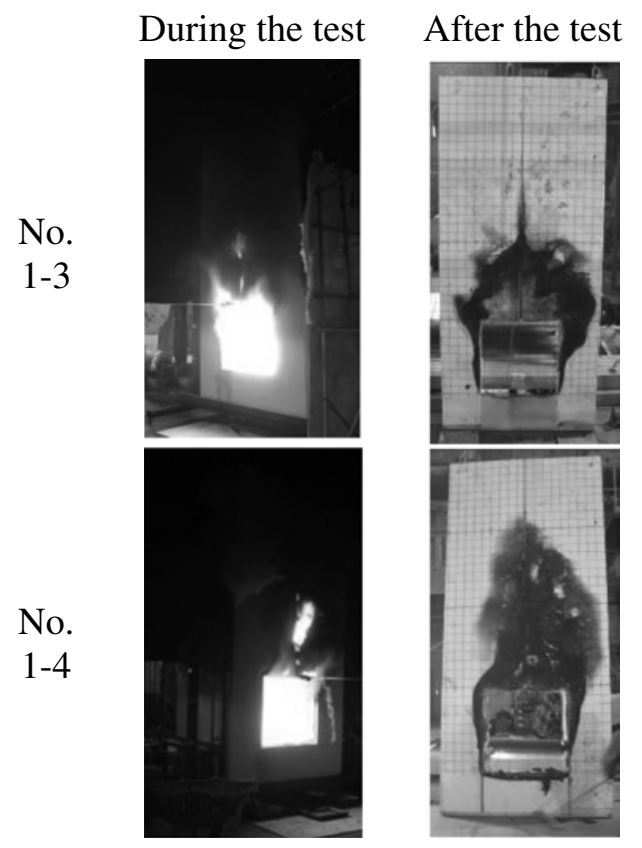

Façade surface temperature
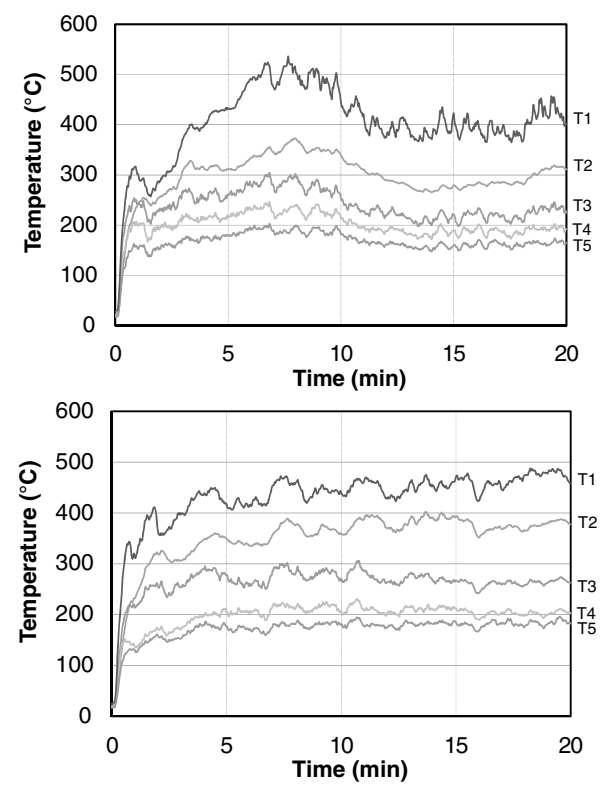

Figure 8. Test result (No. 1-3 and 1-4).

\subsection{Photovoltaic sheet mounted on composite panel $(4 \mathrm{~mm})$}

As a base material to attach photovoltaic sheet on, aluminium composite panel mainly composed of fire-retardant polyethylene core with aluminium facings was selected. Façade tests were conducted with different opening frames (steel or aluminium sheets). For reference, other façade tests were also conducted with the specimens without photovoltaic sheet on base materials (No. 1-5 and 2-5).

On the surface of specimens with photovoltaic sheet (No. 1-6 and 2-6), relatively bigger fire propagation was observed. Especially with the specimen with the aluminium opening (No. 2-6), the upper opening was broken by the gashing flames and flame on the surface spread up to the upper end of the specimen whereas in the case of the specimen with steel opening, the fire propagation stopped in the middle of the specimen's surface. It suggests that the opening frame effects the fire propagation on the surface in the case of relatively combustible materials such as photovoltaic sheet on the surface.

\subsection{Wood}

Façade tests were conducted on wooden materials with different combustibility level of cedar by impregnating chemical and heating treatment. Specimens were installed on wooden furring on calcium 
$1^{\text {st }}$ International Seminar for Fire Safety of Facades, Paris (France), 2013
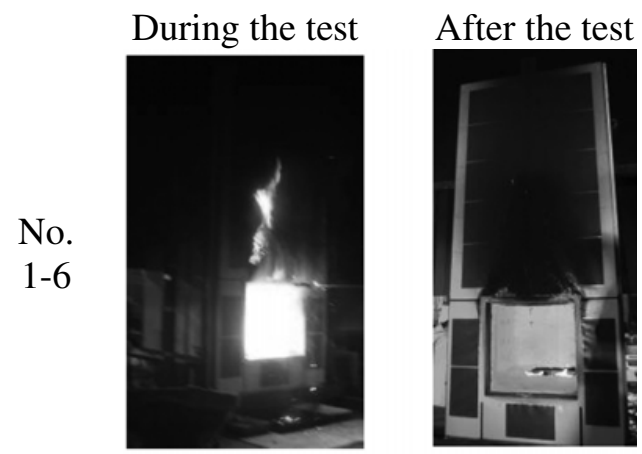

Façade surface temperature
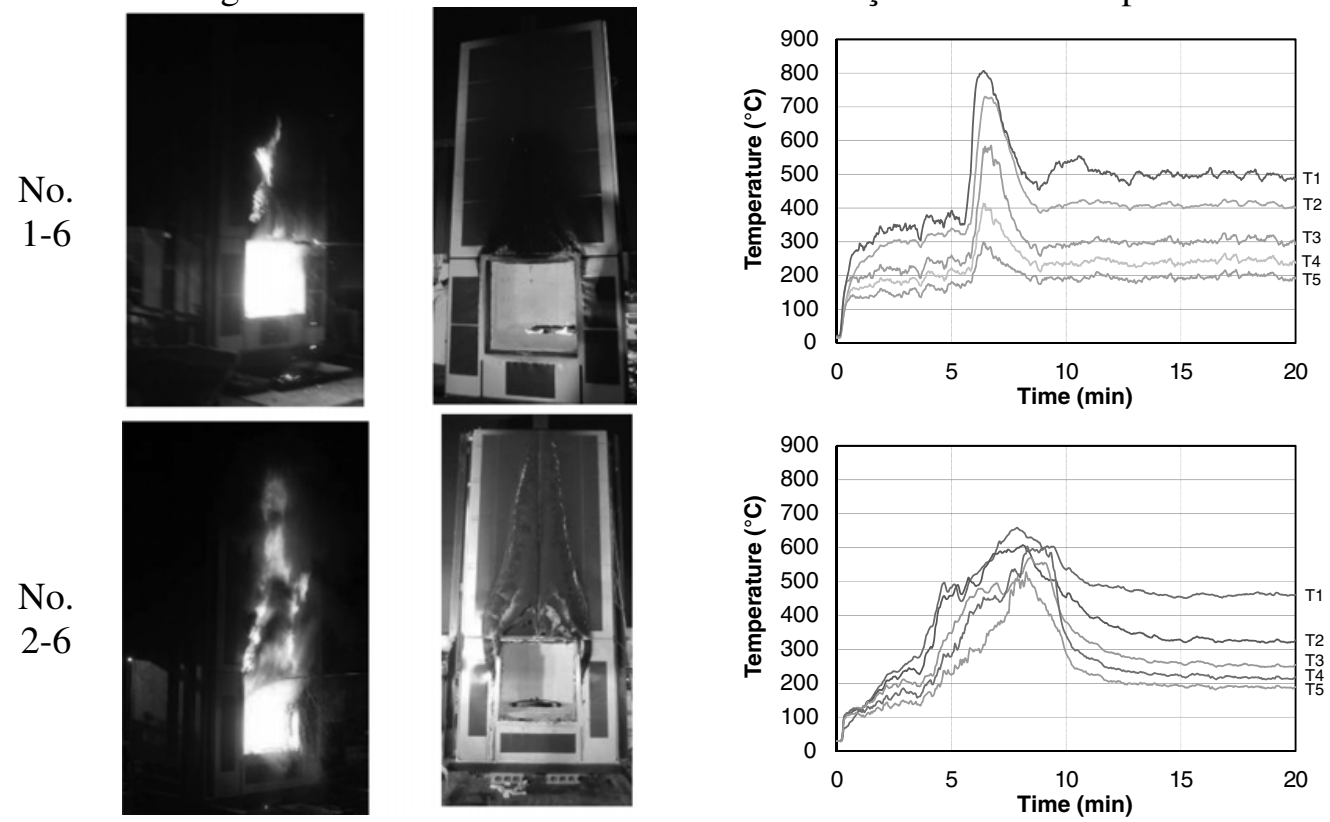

Figure 9. Test result (No. 1-6 and 2-6).

Table 6. Composition of specimens (Photovoltaic sheet mounted on composite panel (4 mm)).

\begin{tabular}{|c|c|c|c|c|}
\hline No. & Core $(3 \mathrm{~mm})$ & Surface & Photovoltaic sheet $(1.3 \mathrm{~mm})$ & Opening frame \\
\hline $1-5$ & \multirow{4}{*}{$\begin{array}{l}\text { Fire-retardant } \\
\text { polyethylene }\end{array}$} & \multirow{4}{*}{$\begin{array}{l}\text { Coated aluminum facing } \\
(0.5 \mathrm{~mm}) \text { on both sides }\end{array}$} & None & Steel sheets \\
\hline $1-6$ & & & mounted & Steel sheets \\
\hline $2-5$ & & & None & Aluminum sheets \\
\hline $2-6$ & & & mounted & Aluminum sheets \\
\hline
\end{tabular}

Table 7. Composition of specimens (Wood).

\begin{tabular}{|c|c|c|c|c|}
\hline \multirow{2}{*}{ No. } & Surface & Wooden type & $\begin{array}{c}\text { Fire retardant } \\
\text { treatment }\end{array}$ & $\begin{array}{c}\text { Material classification } \\
\text { in Japan }\end{array}$ \\
\hline $2-7$ & \multirow{3}{*}{$\begin{array}{c}\text { Horizontal plank on } \\
\text { wooden furring }\end{array}$} & \multirow{3}{*}{ Japanese cedar } & None & Combustible \\
\cline { 1 - 3 } & & Chemical treatment & Fire retardant \\
\cline { 1 - 1 } $2-9$ & & Heat and chemical treatment & Quasi-noncombustible \\
\hline
\end{tabular}

silicate boards and then finally covered with horizontal planks. Specimen's openings are covered with ceramic fibre blankets in order to prevent flames through the opening into furring.

In Japan, the cedar used in No. 2-8 is currently classified as fire retardant material, and the cedar used in No. 2-9 as quasi-noncombustible material. For reference, temperatures were measured on the surface of the substrates, which were also the temperatures at the backside of façade materials (Fig. 10).

For the specimen of cedar without any treatment (No. 2-7), fire propagation on the surface stopped in the middle of the specimen, but finally fire reached upper edge of the specimen because flame from the opening broke the wooden surface and penetrating the specimen.

On the other hand, neither fire propagation nor penetration to backside of façade was observed at specimens with fire retardant treatment (No. 2-8 and 2-9). 

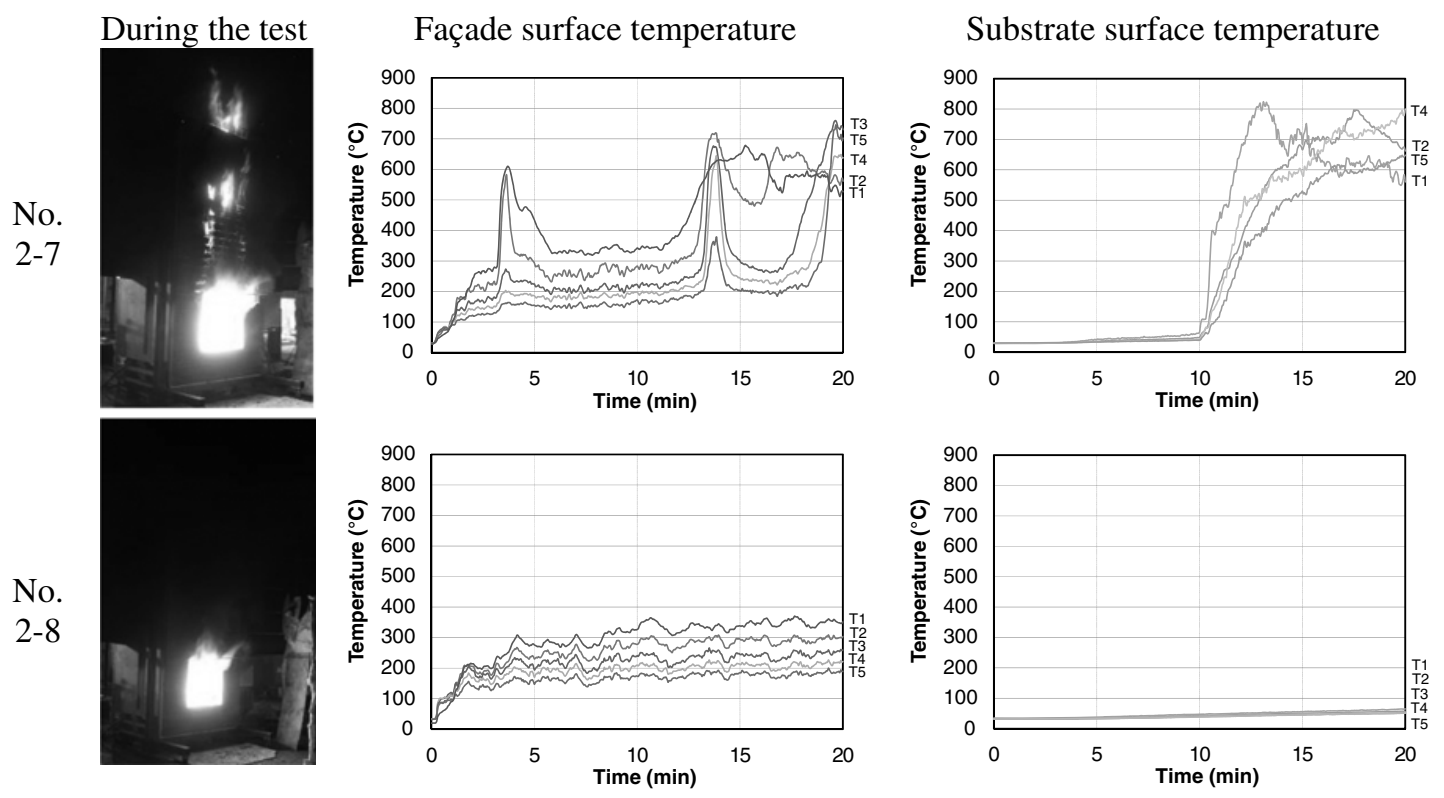

Figure 10. Test result (No. 2-7 and 2-8).

\subsection{Exterior thermal insulation (wet finishing)}

As for exterior thermal insulation (wet finishing), façade tests were conducted with actually constructed exterior thermal insulation in Japan, which mainly consisted of thermal insulation, base mortar, reinforcing net and finishing materials.

Façade tests were conducted on exterior thermal insulation with or without vertical joint, different thickness of EPS, different treatment of edge, different finishing material and different levels of heat intensity.

In the case of thinner insulation $(50 \mathrm{~mm})$, fire propagation was not noticeable although combustible materials (EPS) burned around the upper edge of the opening.

Some of the experimental results are shown in Figure 11. Compared with No. 2-14, in cases of thicker EPS (No. 2-15) and stronger heat intensity (No. 2-17), fire propagation on the surface became larger along the vertical joint and reached even upper edge of the specimens. On the other hand, a specimen without vertical joint (No. 1-11) and a specimen reinforced with anchor and non-combustible boards (No. 2-10), resulted in smaller fire propagation on the surface.

\subsection{Other combustible materials}

Regarding other combustible materials, façade tests were conducted on resin painting, resin siding boards and PMMA sheets.

As a result, resin painting stopped the burning flame near the opening soon after the initiation of fire test. Resin siding boards melted and dropped from furring, and fire propagation was not observed. In the case of PMMA (1 mm thick), limited fire propagation was observed. 
$1^{\text {st }}$ International Seminar for Fire Safety of Facades, Paris (France), 2013

Table 8. Composition of specimens (Exterior thermal insulation (wet finishing)).

\begin{tabular}{|l|c|c|c|c|c|c|}
\hline No. & $\begin{array}{c}\text { Thickness } \\
\text { of EPS }\end{array}$ & $\begin{array}{c}\text { Additional } \\
\text { reinforcement }\end{array}$ & Edge & $\begin{array}{c}\text { Finishing } \\
\text { material }\end{array}$ & $\begin{array}{c}\text { Heat } \\
\text { intensity }\end{array}$ & $\begin{array}{c}\text { Vertical } \\
\text { joint }\end{array}$ \\
\hline $1-7$ & $50 \mathrm{~mm}$ & None & Aluminum frame & Fire-retardant & $600 \mathrm{~kW}$ & Without \\
\hline $1-8$ & $50 \mathrm{~mm}$ & None & Back-wrapping & Combustible & $600 \mathrm{~kW}$ & Without \\
\hline $1-9$ & $50 \mathrm{~mm}$ & None & Back-wrapping & Combustible & $600 \mathrm{~kW}$ & With \\
\hline $1-10$ & $100 \mathrm{~mm}$ & None & Back-wrapping & Combustible & $600 \mathrm{~kW}$ & Without \\
\hline $1-11$ & $100 \mathrm{~mm}$ & None & Back-wrapping & Combustible & $600 \mathrm{~kW}$ & Without \\
\hline $2-10$ & $100 \mathrm{~mm}$ & Anchor pin & Calcium silicate boards & Fire-retardant & $600 \mathrm{~kW}$ & With \\
\hline $2-11$ & $100 \mathrm{~mm}$ & None & Back-wrapping & Combustible & $600 \mathrm{~kW}$ & With \\
\hline $2-12$ & $200 \mathrm{~mm}$ & None & fire-retardant material & Combustible & $600 \mathrm{~kW}$ & With \\
\hline $2-13$ & $50 \mathrm{~mm}$ & None & Back-wrapping & Noncombustible & $600 \mathrm{~kW}$ & With \\
\hline $2-14$ & $100 \mathrm{~mm}$ & None & Back-wrapping & Combustible & $600 \mathrm{~kW}$ & With \\
\hline $2-15$ & $150 \mathrm{~mm}$ & None & Back-wrapping & Combustible & $600 \mathrm{~kW}$ & With \\
\hline $2-16$ & $100 \mathrm{~mm}$ & None & Back-wrapping & Combustible & $700 \mathrm{~kW}$ & Without \\
\hline $2-17$ & $100 \mathrm{~mm}$ & None & Back-wrapping & Combustible & $700 \mathrm{~kW}$ & With \\
\hline $2-18$ & $100 \mathrm{~mm}$ & None & Fire-retardant material & Combustible & $600 \mathrm{~kW}$ & With \\
\hline
\end{tabular}

Table 9. Composition of specimens (Other combustible materials).

\begin{tabular}{|l|c|c|c|}
\hline No. & Classification & Details & Vertical joint \\
\hline $1-12$ & Resin painting & $\begin{array}{r}\text { Water resistant exterior finish paint on calcium silicate } \\
\text { boards(Coated thickness:2‘3 mm) }\end{array}$ & Without \\
\hline $1-13$ & Resin siding boards & Extruded vinyl chloride resin with furring & With \\
\hline $2-19$ & Acrylic sheet & PMMA (1 mm thick) on calcium silicate boards & Without \\
\hline
\end{tabular}

Table 10. Test results (temperature in ${ }^{\circ} \mathrm{C}$ ).

\begin{tabular}{|c|c|c|c|c|c|c|c|c|c|c|c|}
\hline No. & T1 & T2 & T3 & T4 & T5 & No. & T1 & $\mathbf{T} 2$ & T3 & T4 & $\Gamma 5$ \\
\hline 1-B & 434 & 374 & 280 & 221 & 189 & 2-B & 420 & 345 & 277 & 223 & 186 \\
\hline $1-1$ & 439 & 378 & 322 & 260 & 225 & $2-1$ & 314 & 291 & 257 & 224 & 202 \\
\hline $1-2$ & 483 & 432 & 369 & 320 & 264 & $2-2$ & 404 & 351 & 282 & 249 & 217 \\
\hline $1-3$ & 536 & 373 & 304 & 246 & 203 & $2-3$ & 551 & 398 & 273 & 229 & 198 \\
\hline $1-4$ & 488 & 403 & 306 & 230 & 196 & $2-4$ & 470 & 363 & 289 & 239 & 210 \\
\hline $1-5$ & 513 & 392 & 290 & 239 & 188 & $2-5$ & 443 & 308 & 254 & 223 & 196 \\
\hline $1-6$ & 807 & 730 & 585 & 414 & 299 & $2-6$ & 659 & 607 & 570 & 603 & 527 \\
\hline 1-7 & 438 & 357 & 297 & 243 & 197 & $2-7$ & 679 & 720 & 759 & 648 & 746 \\
\hline $1-8$ & 572 & 451 & 342 & 267 & 223 & $2-8$ & 370 & 309 & 266 & 227 & 200 \\
\hline $1-9$ & 645 & 469 & 369 & 289 & 224 & $2-9$ & 382 & 311 & 240 & 212 & 185 \\
\hline $1-10$ & 623 & 539 & 353 & 290 & 245 & $2-10$ & 463 & 373 & 283 & 235 & 203 \\
\hline $1-11$ & 561 & 530 & 327 & 265 & 225 & $2-11$ & 498 & 394 & 323 & 282 & 245 \\
\hline $1-12$ & 571 & 408 & 326 & 263 & 219 & $2-12$ & 510 & 415 & 280 & 236 & 220 \\
\hline \multirow[t]{7}{*}{$1-13$} & 519 & 459 & 360 & 293 & 243 & $2-13$ & 363 & 319 & 245 & 231 & 204 \\
\hline & & & & & & $2-14$ & 566 & 406 & 297 & 261 & 230 \\
\hline & & & & & & $2-15$ & 655 & 616 & 531 & 672 & 573 \\
\hline & & & & & & $2-16$ & 686 & 507 & 401 & 289 & 250 \\
\hline & & & & & & $2-17$ & 647 & 589 & 347 & 412 & 526 \\
\hline & & & & & & $2-18$ & 475 & 372 & 286 & 248 & 217 \\
\hline & & & & & & $2-19$ & 368 & 370 & 289 & 229 & 209 \\
\hline
\end{tabular}


MATEC Web of Conferences
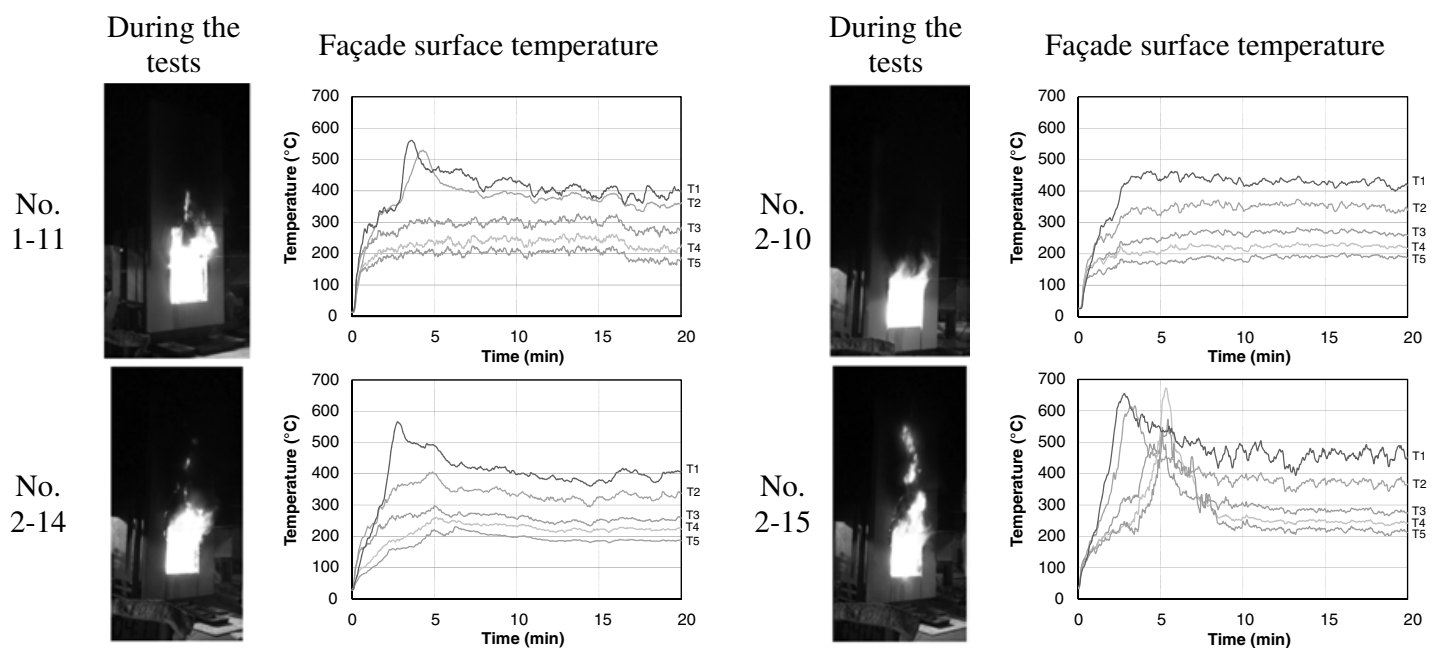

No.

2-14

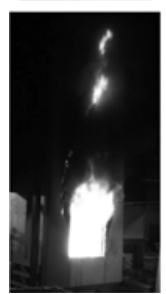

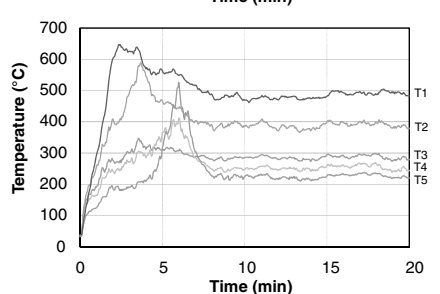

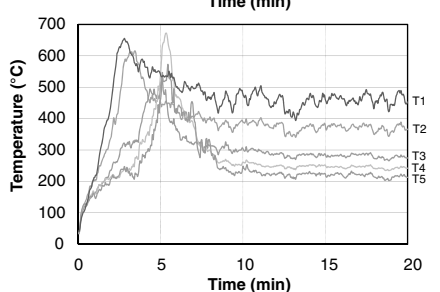

Figure 11. Test result (No. 1-11,2-10,2-14,2-15 and 2-17).

\subsection{Summary}

As a result, relatively massive fire propagation was observed with some specimens, i.e. facade of exterior thermal insulation (XPS) with vent layer, photovoltaic sheet mounted on composite panel, exterior thermal insulation system including relatively thick insulation materials (EPS), and wood without fire retardant treatment.

From these experimental results, it was confirmed how vent layer, materials of opening frame, combustibility of insulation materials have an influence on fire propagation.

\section{COMPARISON OF SURFACE TEMPERATURE}

Test results of average temperatures of calibration tests were summarized and the highest temperatures of each specimen were shown in Table 10.

As for the calibration test, average values have resulted in exceeding general timber flash points in T1, T2 and T3. Compared with calibration average, measured highest temperatures are not much high numerically in a lot of combustible test specimens. With only five specimens (No. 1-6, 2-6, 2-7, 2-15 and 2-17), relatively higher temperatures were measured even at higher elevations of specimens and fire propagation properties were numerically confirmed. Therefore it is necessary to conduct a further study on more specimens, which will be more vulnerable to fire in order to establish the fire safety criteria for evaluating fire propagation over combustible facade systems.

\section{CONCLUSIONS}

Based on the façade-type fire propagation test proposed by authors in the previous study [1], in this research paper, façade fire tests were conducted on specimens of various combustible exterior wall 
systems in order to confirm fire propagation properties on façade when it was subject to ejected flame from an opening of combustion chamber. The temperatures at façade surface were measured and compared among the façade specimens.

It is suggested that massive fire propagation on combustible exterior wall systems would not occur without sufficient air supply to combustible materials during fire, or when combustible materials have self-extinguishing properties. In this study, massive fire propagation was not observed with some specimens. Therefore it is necessary to conduct a further study with more specimens which are more vulnerable to fire for establishing the fire safety criteria for evaluating fire propagation over combustible exterior wall systems. Last but not least, façade test method used in this research will be submitted to JSA (Japanese Standards Association) in November 2013 and be standardized in Japan. Also, criteria based on this façade test shall also be discussed.

Members of Consortium for Building Research \& Development (CBRD) are appreciated for their support on preparation for façade specimens.

\section{References}

[1] H. Yang et al.: "Basic Research of Fire Properties of Exterior Insulation and Finish Systems, Part3: Reaction-to-fire tests for facades - Intermediate-scale test (ISO 13785-1)," Summaries of Technical Papers of Annual Meeting, Architectural Institute of Japan, 2009 (in Japanese).

[2] H. Yoshioka et al.: "Study of Test Method for Evaluation of Fire Propagation along Façade Wall with Exterior Thermal Insulation," Fire Science and Technology, Vol. 30 (2011) No. 1, pp.27-44.

[3] H. Yoshioka et al.: "Large-scale Facade Fire Tests Conducted Based on ISO 13785-2 with Noncombustible Facade Specimens," Fire Science and Technology, Vol. 31 (2012) No. 1, pp. 1-22. 